\title{
Trichostatin A enhances acetylation as well as protein stability of ERa through induction of p300 protein
}

Sung-Hye Kim1,2,3, Hyun-Jin Kang 1,2,3, Hyelin Na1,2,3 and Mi-Ock Lee*1,2,3

\begin{abstract}
Introduction: Trichostatin A (TSA) is a well-characterized histone deacetylase (HDAC) inhibitor. TSA modifies the balance between HDAC and histone acetyltransferase activities that is important in chromatin remodeling and gene expression. Although several previous studies have demonstrated the role of TSA in regulation of estrogen receptor alpha (ERa), the precise mechanism by which TSA affects ERa activity remains unclear.

Methods: Transient transfection was performed using the Welfect-EXTMPlus procedure. The mRNA expression was determined using RT-PCR. Protein expression and interaction were determined by western blotting and immunoprecipitation. The transfection of siRNAs was performed using the Oligofectamine ${ }^{\mathrm{TM}}$ reagent procedure.

Results: TSA treatment increased acetylation of ERa in a dose-dependent manner. The TSA-induced acetylation of ERa was accompanied by an increased stability of ERa protein. Interestingly, TSA also increased the acetylation and the stability of p300 protein. Overexpression of p300 induced acetylation and stability of ERa by blocking ubiquitination. Knockdown of p300 by RNA interference decreased acetylation as well as the protein level of ERa, indicating that p300 mediated the TSA-induced stabilization of ERa.

Conclusions: We report that TSA enhanced acetylation as well as the stability of the ERa protein by modulating stability of $\mathrm{p} 300$. These results may provide the molecular basis for pharmacological functions of HDAC inhibitors in the treatment of human breast cancer.
\end{abstract}

\section{Introduction}

Estrogen receptors (ERs) are members of a nuclear hormone receptor superfamily. ERs exist in two isoforms, ER $\alpha$ and ER $\beta$, which have highly conserved DNA binding domains and ligand binding domains $[1,2]$. Although these receptors display similar binding affinities for $17 \beta$-estradiol, they have distinct roles in the regulation of gene expression and different interactions with unique sets of transcriptional factors [2]. Activation of ER $\alpha$ is considered a risk factor for the development of breast cancer, since the activation leads to cellular proliferation [3,4]. Cumulative data from tumor biopsies in the clinic have shown that twothirds of breast cancers are ER-positive [5,6]. Tamoxifen, which regulates ER $\alpha$ activity, reduces the recurrence and death rate of ER $\alpha$-positive breast cancer [7]. Breast cancer

* Correspondence: molee@snu.ac.kr

${ }^{1}$ College of Pharmacy, Seoul National University, San 56-1, Sillim-dong, Kwanak-gu, Seoul 151-742, Republic of Korea

Full list of author information is available at the end of the article patients with expression of ER $\alpha$ are seven to eight times more likely to benefit from selective estrogen receptor modulators such as tamoxifen than ER $\alpha$-negative patients [5]. ER $\alpha$ expression is therefore considered a significant outcome predictor for breast cancer patients to endocrine therapy.

The function of ER $\alpha$ is regulated by post-translational modifications such as phosphorylation [8,9], acetylation [10,11], sumoylation [12], and ubiquitination [13]. Among these modifications, acetylation is emerging as a central process in transcriptional activation of ER $\alpha$ [14]. ER $\alpha$ is directly acetylated by p300 at lysine 302 and 303 in the absence of ligand, and its acetylation regulates transcriptional activation and ligand sensitivity [10]. ER $\alpha$ is also acetylated at lysine 266 and 268 in the presence of coactivators p160 and p300, which enhances not only DNA binding but also transactivation activities. This acetylation was reversed by native cellular deacetylases, including trichos- 
tatin A (TSA)-sensitive class I and II histone deacetylases (HDACs), and nicotinamide adenine dinucleotide-dependent HDACs (class III, such as Sirt1) [11].

Generally, TSA is known to modify the balance between histone acetyltransferase and HDAC activities that induce histone hyperacetylation and regulate gene expression. Recently, the effect of TSA in acetylation/deacetylation of nonhistone proteins has been demonstrated as a diverse regulatory event, including ubiquitination/proteasomal degradation [15]. TSA effectively represses the mRNA and protein level of ER $\alpha$ in the ER $\alpha$-positive breast cancer cells $[16,17]$. Although several previous studies have demonstrated the role of TSA-dependent HDACs in regulation ER $\alpha$ activity [18-20], the precise mechanism of TSAinduced activation of ER $\alpha$ remains unclear. We therefore explored whether TSA induces acetylation of ER $\alpha$ and increases stability of $\mathrm{ER} \alpha$ in the present investigation.

\section{Materials and methods Cell and cell culture}

The breast adenocarcinoma cell line T47D (ATCC HB $8065)$ and the human cervical carcinoma cell line HeLa (ATCC CCL-2) were obtained from the American Type Culture Collection (Manassas, VA, USA). Cells were maintained in Dulbecco's modified Eagle's medium containing $10 \%$ fetal bovine serum at $37^{\circ} \mathrm{C}$ in a $5 \% \mathrm{CO}_{2} / 95 \%$ air incubator.

\section{Plasmids, siRNA and transient transfection}

The Myc-tagged ER $\alpha$, pCMV-Myc-ER $\alpha$, was constructed by inserting a PCR-amplified full-length human ER $\alpha$ fragment into the EcoRI/Sall site of pCMV-Myc. The Mycp300 expression vectors were gifted from Dr SC Bae (Chungbuk National University, Cheongju, Korea). The Myc epitope does not contain the known acetylated lysine residues $[21,22]$. Transient expression of proteins in HeLa cells was as described previously [23]. The siRNA duplexes targeting p300 and nonspecific siRNA (siGFP) were transfected as previously described [24,25].

\section{Western blotting and immunoprecipitation}

Western blotting and immunoprecipitation were performed as previously described using specific antibodies against ER $\alpha$, p300, Myc (Santa Cruz Biotechnology, Santa Cruz, CA, USA), and $\alpha$-tubulin (Calbiochem, Darmstadt, Germany) [23]. To detect acetylated proteins, $500 \mu \mathrm{g}$ whole cell lysates were incubated with $1 \mu \mathrm{g}$ anti-pan-acetyl antibody (Santa Cruz Biotechnology) or anti-acetylated-lysine antibody (Cell Signaling Technology, Danvers, MA, USA), precipitated by adding $50 \mu \mathrm{l}$ protein-A or protein-G agarose slurry, and then probed with specific antibodies or normal IgG. Acetylation of proteins was confirmed by reciprocal immunoprecipitation and western blotting. To detect ubiquitinated proteins, whole cell lysates were immunoprecipi- tated by $1 \mu \mathrm{g}$ anti-ubiquitin antibody or anti-Myc antibody (Santa Cruz Biotechnology), and were probed using antiMyc antibody or anti-ubiquitin antibody, respectively. Representative data from at least three independent experiments are shown.

\section{Reverse transcriptase-polymerase chain reaction}

Total RNA was prepared using the Easy-Blue ${ }^{\mathrm{TM}}$ total RNA extraction kit (iNtRON Biotechnology, Seongnam, Korea) according to the manufacturer's instructions. PCR was performed as described previously using specific primers for $\mathrm{ER} \alpha$ [26] and p300 [27]. The expression of $\beta$-actin was monitored as a control.

\section{Results \\ Trichostatin A enhances acetylation as well as stability of ERa protein}

Although previous studies have demonstrated that TSAdependent HDACs regulated $\mathrm{ER} \alpha$ activity, the precise mechanism remains unclear. We therefore explored the possibility that TSA induced acetylation of $\operatorname{ER} \alpha$ and thereby affected the stability of ER $\alpha$.

ER $\alpha$ was acetylated in the presence of $1 \mu \mathrm{M}$ TSA when examined using anti-acetylated-lysine antibody in the human ER $\alpha$-positive breast cell line, T47D (Figure 1a). We also found that the protein level of $\mathrm{ER} \alpha$ was increased in the presence of TSA in a dose-dependent manner; the level was increased with as low as $0.1 \mu \mathrm{M}$ TSA (Figure 1b). The mRNA level, however, was not altered. This result suggests that the TSA-induced $\operatorname{ER} \alpha$ may be due to increases in protein stability, not increases in the transcriptional level. We next studied the effect of TSA on the acetylation of $\mathrm{ER} \alpha$, expression of which is controlled by cytomegalovirus promoter using transient transfection of pCMV-ER $\alpha$ in HeLa cells. TSA also increased acetylation as well as the protein level of ER $\alpha$ in HeLa cells (Figure 1c, d). When acetylation was measured with similar amounts of ER $\alpha$ in the presence of an inhibitor of proteasome, MG132, the increase of acetylation in the presence of TSA was obvious, indicating that TSA affected protein stability but not transcription of ER $\alpha$ (Figure 1e). When the stability of ER $\alpha$ was measured using cycloheximide, a blocker of de novo protein synthesis, we observed that treatment of TSA blocked degradation of $\operatorname{ER} \alpha$ (Figure 1f).

\section{Trichostatin A increases acetylation and protein stability of p300}

It has been reported that $\mathrm{ER} \alpha$ is directly acetylated by p300 at the well-conserved lysine residues in the hinge and ligand binding domain [10]. p300 acetylates itself, and the resulting conformational change modulates its transactivation potential $[28,29]$.

We therefore investigated whether treatment of TSA increased the acetylation of p300 and thereby affected the 


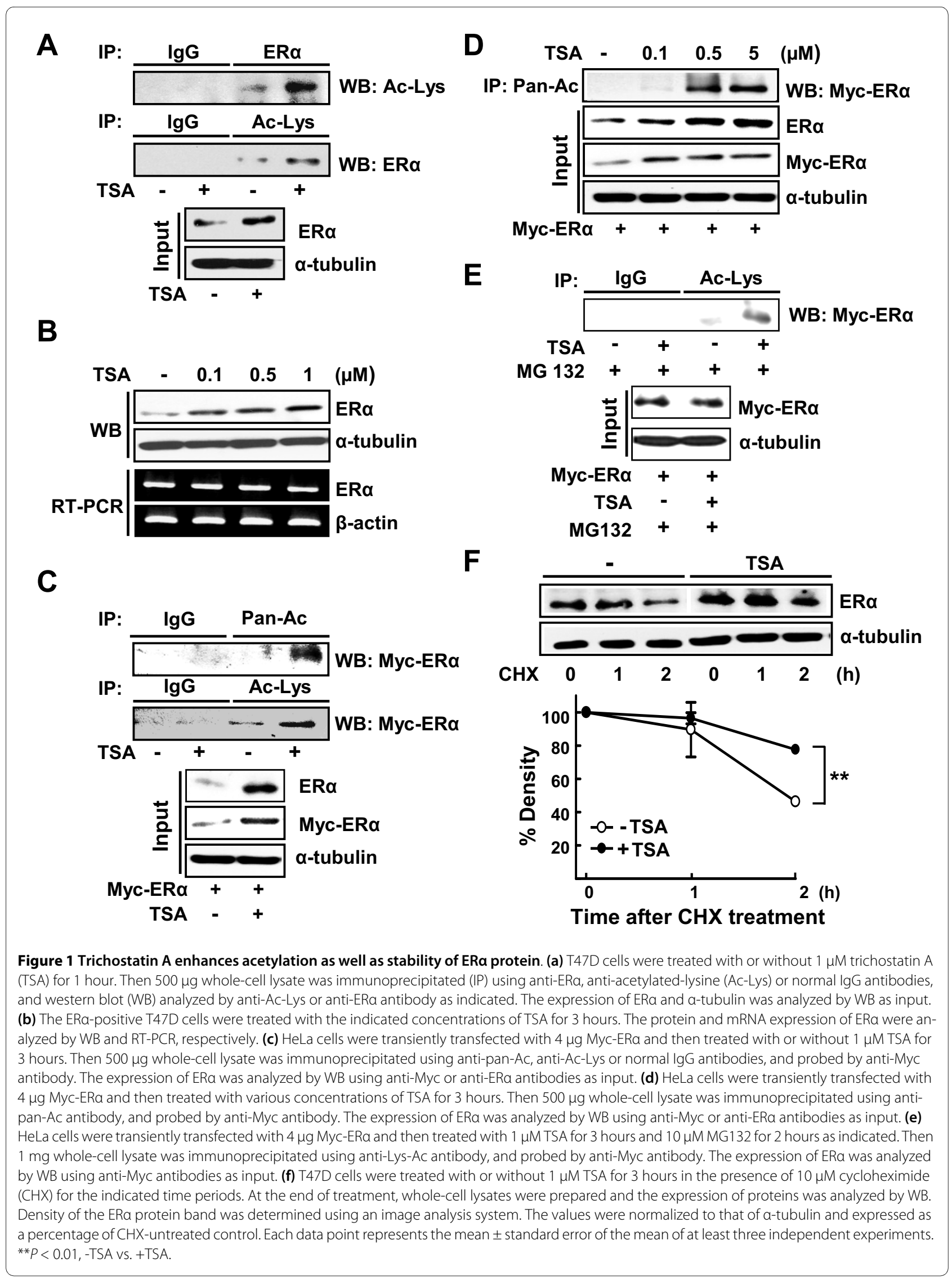


acetylation level of ER $\alpha$. As expected, acetylation of p300 was increased in the presence of TSA in T47D cells (Figure 2a). This observation suggests that the TSA-dependent HDACs are associated with deacetylation of p300. Similar to $\mathrm{ER} \alpha$, the protein level of p300 was significantly increased in the presence of TSA in a dose-dependent and time-dependent manner; however, the mRNA level of p300 was not altered (Figure 2b). Similar results were observed in p300 proteins overexpressed in HeLa cells (Figure 2c, d). The increase in acetylation of p300 was clearly observed in the presence of TSA when degradation of p300 was blocked by an inhibitor of proteasome, MG132 (Figure 2e). This result indicates that TSA affected protein stability rather than transcription of $\mathrm{p} 300$. The protein level of $\mathrm{p} 300$ was maintained by TSA in the presence of cycloheximide, indicating that TSA increases the protein stability of p300 (Figure 2f).

\section{p300 enhances the acetylation and stability of ERa protein} We then examined whether $\mathrm{p} 300$ increased acetylation and stability of the ER $\alpha$ protein. When p300 was exogenously introduced together with ER $\alpha$ in HeLa cells, acetylation as well as the protein level of ER $\alpha$ were largely increased (Figure 3a). The increase in ER $\alpha$ depended on the amount of p300 expressed (Figure 3b). We also found that ER $\alpha$ was physically associated with p300 in the presence of TSA by co-immunoprecipitation assays (Figure 3c).

The protein level of ER $\alpha$ was maintained in the presence of p300 while it largely decreased in the absence of p300, when cells were treated with cycloheximide for 3 hours (Figure 4a). Ubiquitination of ER $\alpha$ was dramatically repressed in the presence of $\mathrm{p} 300$. These results indicate that $\mathrm{p} 300$-induced acetylation of $\mathrm{ER} \alpha$ is associated with blocking proteasomal degradation of $\operatorname{ER} \alpha$ (Figure $4 \mathrm{~b}$ ). Finally, we confirmed the role of p300 in TSA-induced ER $\alpha$ protein stability after knockdown of p300 using RNA interference. As shown in Figure 5, the TSA-induced acetylation and the increase in the protein level of ER $\alpha$ were largely diminished when expression of p300 was repressed, in both T47D and HeLa cells.

Together, these results demonstrated that TSA increased the stability of ER $\alpha$ protein by enhancing acetylation and stabilization of $\mathrm{p} 300$.

\section{Discussion}

TSA not only inhibits growth of ER $\alpha$-positive breast cancer cells in vitro but also inhibits breast tumor growth in vivo $[16,17,30]$. TSA may exert these beneficial effects against tumor growth by blocking deacetylation of histones and transcriptional factors, which subsequently alters transcriptional activity of target genes [15,31]. Here we report that TSA induces stability of ER $\alpha$ protein by enhancing acetylation and stability of p300, which may contribute to pharmacological effects of TSA.
Previous studies demonstrated that ER $\alpha$ is acetylated at multiple lysine residues, which may have different functions in the regulation of ER $\alpha$ activity. ER $\alpha$ was acetylated at lysine 266 and 268 in the presence of ligand in a steroid receptor coactivator-dependent manner [11]. ER $\alpha$ was also acetylated at lysine 302 and 303 in the presence of p300, and thereby regulated transcriptional activation and ligand sensitivity of $\operatorname{ER} \alpha$ [10]. Ubiquitination at the same lysine residues was shown to regulate degradation of $\operatorname{ER} \alpha$ [13]. The TSA-induced acetylation of $\operatorname{ER} \alpha$ was accompanied with increased protein level of $\operatorname{ER} \alpha$ (Figure 1), and p300 protected ubiquitination of ER $\alpha$ in our investigation (Figure 4b) - supporting the hypothesis that acetylation of ER $\alpha$, probably at lysine 302 and 303 residues, is important for maintaining protein stability.

This observation is similar to the p300-induced acetylation of p53 or that of Smad7, which blocks ubiquitination and degradation of the protein $[32,33]$. Other nuclear receptors such as LXR $\alpha$ and AR are also present as acetylated forms that are involved in transactivation and other post-translational modifications such as ubiquitination [34,35]. Our finding contrasts, however, with previous reports that TSA downregulated the protein and mRNA level of ER $\alpha$ in ER $\alpha$ positive breast cancer cells $[16,17]$. When MCF7 or T47D cells were treated with TSA for a prolonged period, we also observed a similar downregulation of $\mathrm{ER} \alpha$, indicating that TSA may affect ER $\alpha$ activity through at least two different mechanisms: transcriptional repression of the ER $\alpha$ promoter, and protein stability of ER $\alpha$ at the post-translational level. TSA may accomplish its beneficial effects against breast cancer by inducing sequential and/or divergent modifications of $\mathrm{ER} \alpha$ at different regulation levels.

p300 was originally identified as E1A, which is a transcriptional co-activator for various transcription factors, including $\mathrm{ER} \alpha$ [36]. The intrinsic histone acetyltransferase activity of p300 catalyzes acetylation of histone, which induces chromatin remodeling and subsequent transcriptional activation of target genes. p300 also acetylates nonhistone proteins such as p53 and Smad7, which leads to stabilization of target proteins [33,37]. Interestingly, the histone acetyltransferase domain of p300 acetylates itself [28]. Blanco-García and colleagues demonstrated recently that PCAF was acetylated by itself and by p300. Deacetylation of PCAF was catalyzed mainly by HDAC3, which affected subcellular localization of PCAF [38]. In the case of p300, acetylation was shown to increase transactivation activity and protein-protein interactions [28,29]. In the present study, we found another role for acetylation of p300 in the stabilization of p300 protein itself. Stabilization of p300 is induced within 3 hours of TSA treatment, which is similar to the TSA-induced acetylation and stabilization of ER $\alpha$ (Figure 2). Our finding, however, contradicts previous observations that autoacetylation of p300 did not alter its stability [29]. We believe this conflict may be due 


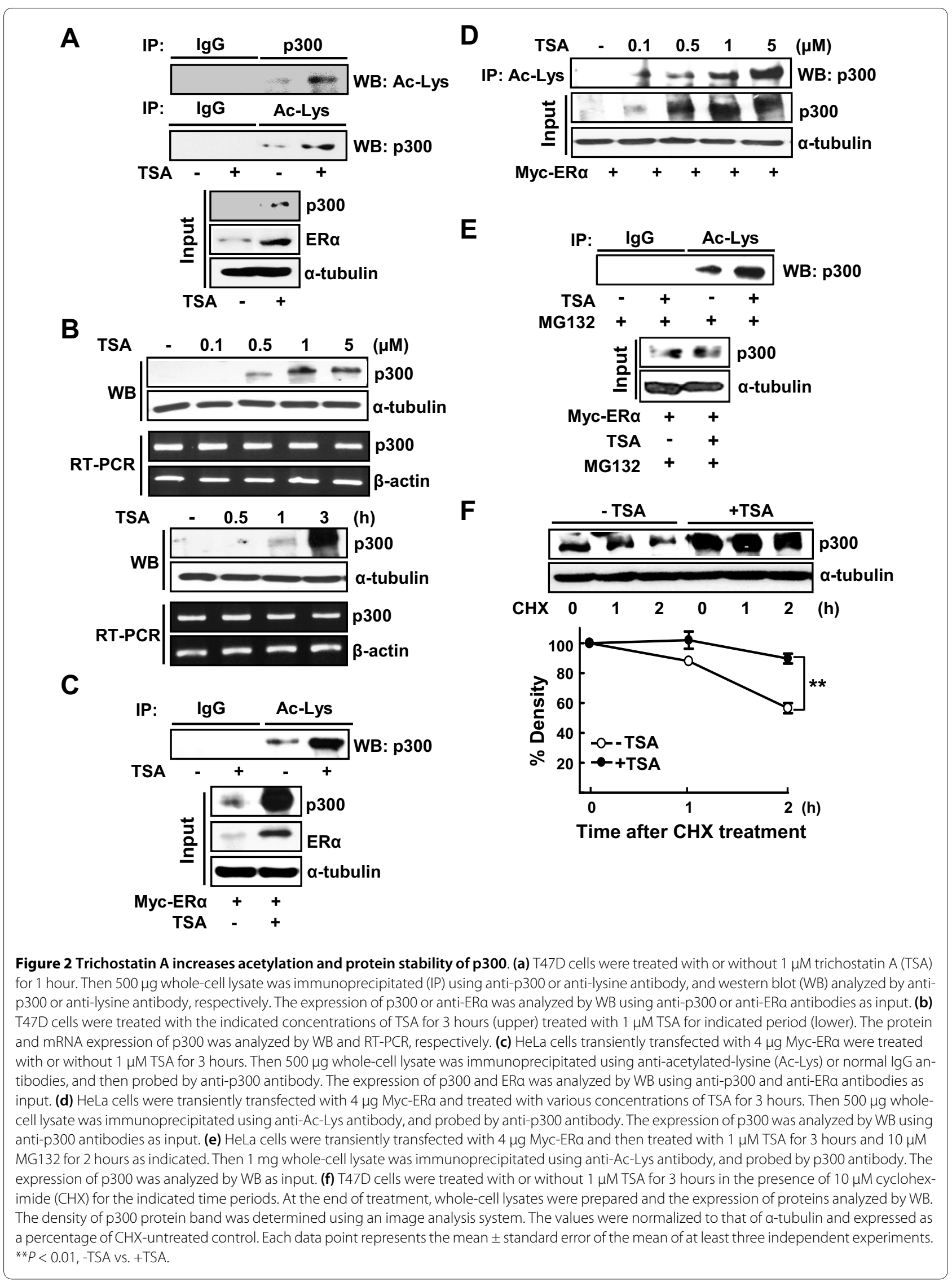




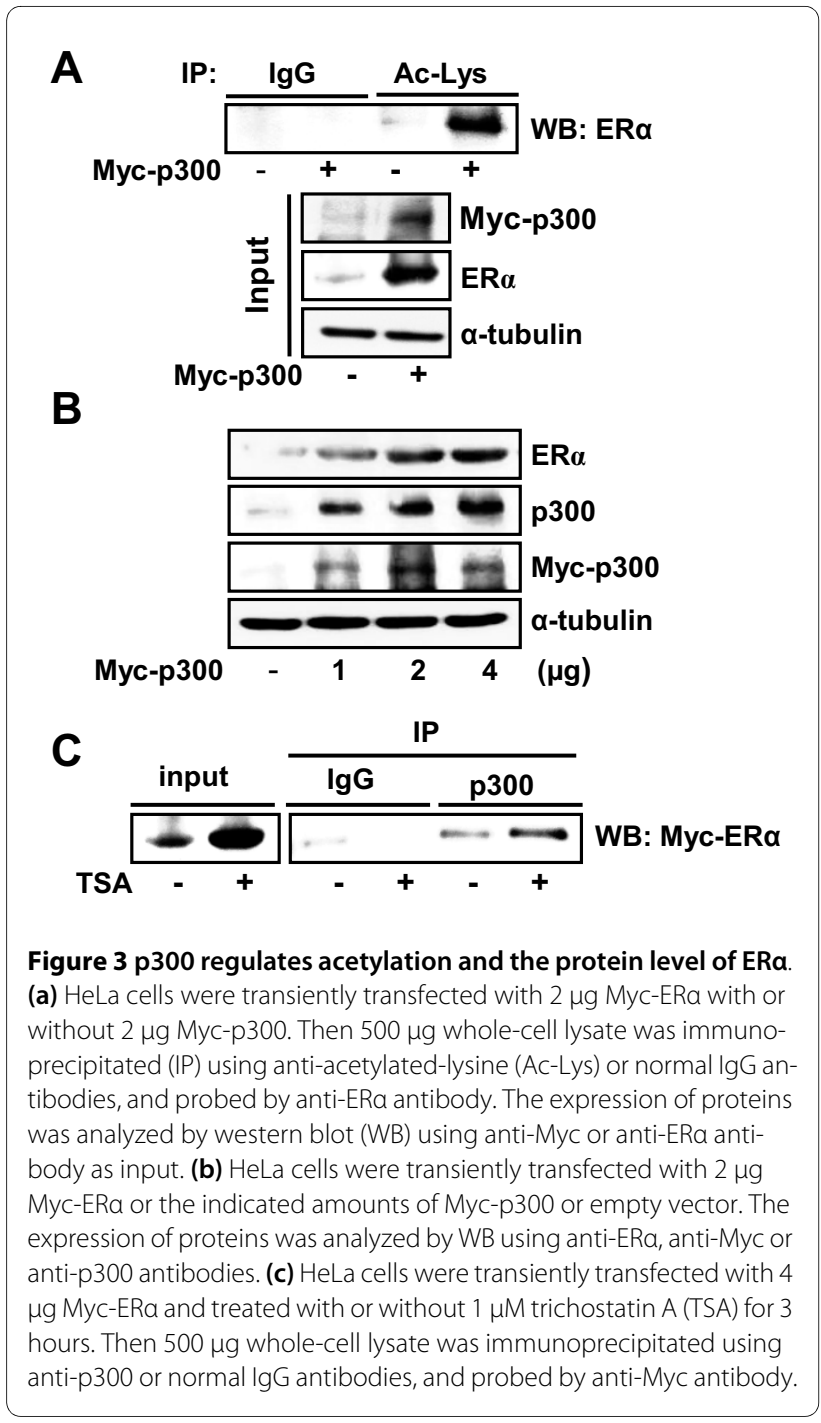

to different experimental conditions such as the expression level of p300 and the cell lines examined. Since p300 mediates acetylation of many proteins including histone and $\mathrm{ER} \alpha$, acetylation and subsequent stabilization of $\mathrm{p} 300$ may regulate the pharmacological effects of TSA through activation of diverse cellular transcription factors in breast cancer cells.

Our results together with those of other studies strongly suggest that the TSA-dependent HDACs are involved in acetylation of ER $\alpha$ [18-20]. The TSA-sensitive HDACs are class I and class II, which form a multiprotein repressor complex to remove the acetyl group from lysine residues of histones [39]. Indeed, HDAC1 and HDAC4, which belong to class I and class II, respectively, interacted with ER $\alpha$ and suppressed the transcriptional activity and expression of $\operatorname{ER} \alpha[18,19]$. On the contrary, nicotinamide adenine dinucleotide-dependent HDACs such as Sirt1 have been demonstrated to deacetylate ER $\alpha$, probably at lysine 266 and 268, which enhanced the DNA binding and transactivation of

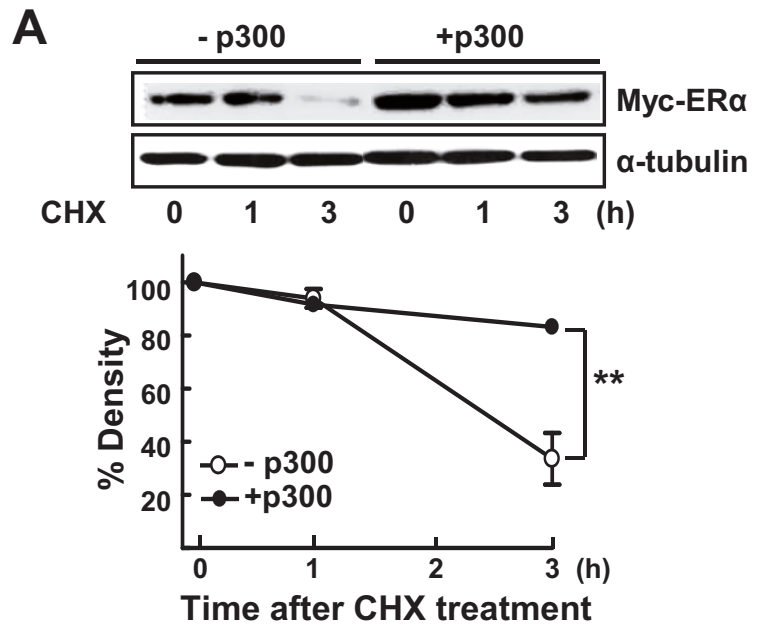

B

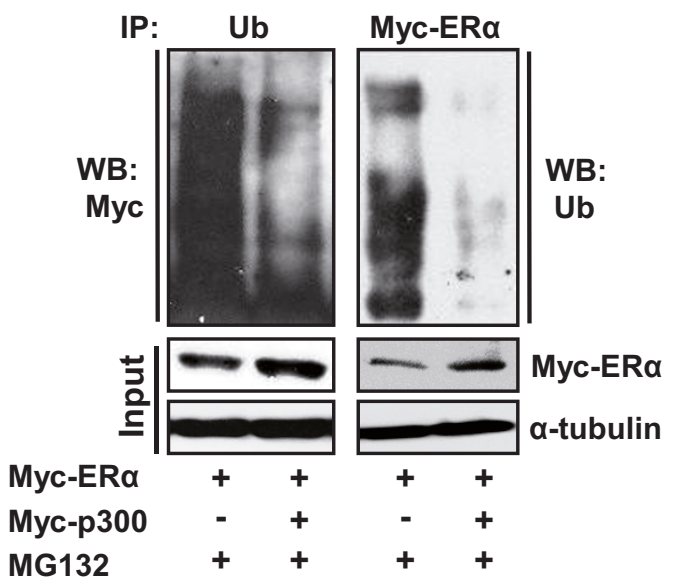

Figure 4 p300 increases protein stability of ERa. (a) HeLa cells were transiently transfected with $2 \mu \mathrm{g}$ Myc-ERa together with $2 \mu \mathrm{g} \mathrm{Myc-}$ p300 or empty vector. At 24 hours after transfection, cells were treated with $20 \mu \mathrm{M}$ cycloheximide (CHX) for the indicated time periods. The expression of protein was analyzed by western blot (WB) using antiMyc antibody (upper). The density of ERa protein band was determined using an image analysis system. The values were normalized to that of a-tubulin and expressed as a percentage of $\mathrm{CHX}$-untreated control (lower). Each data point represents the mean \pm standard error of the mean of three independent experiments. ${ }^{* *} P<0.01,-p 300 \mathrm{vs}$. $+p 300$. (b) HeLa cells were transiently transfected with $4 \mu \mathrm{g}$ Myc-ERa together with $2 \mu \mathrm{g}$ Myc-p300 or empty vector. At 24 hours after transfection, cells were treated with $10 \mu \mathrm{M} \mathrm{MG} 132$ for 2 hours. Then $500 \mu \mathrm{g}$ whole-cell lysate was immunoprecipitated (IP) using anti-ubiquitin (Ub) or anti-Myc antibody and probed by anti-Myc or anti-Ub antibody, respectively. The expression of ERa was analyzed by WB using anti-Myc antibody as input.

$\mathrm{ER} \alpha[11,40]$. It would be interesting to know the unique function of each HDAC subtype as well as of each lysine residue in the regulation of $\mathrm{ER} \alpha$ activity, such as protein stability and transactivation function. Especially, resveratrol - a Sirt1 activator - caused inhibition of estrogen-depen- 


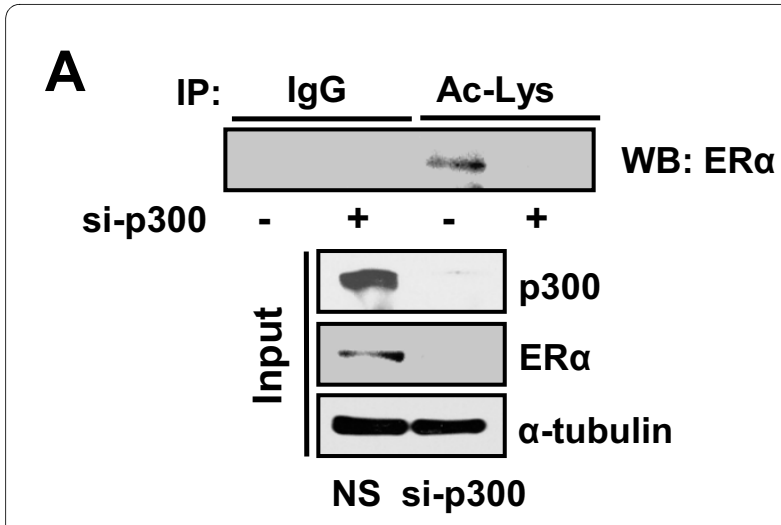

B

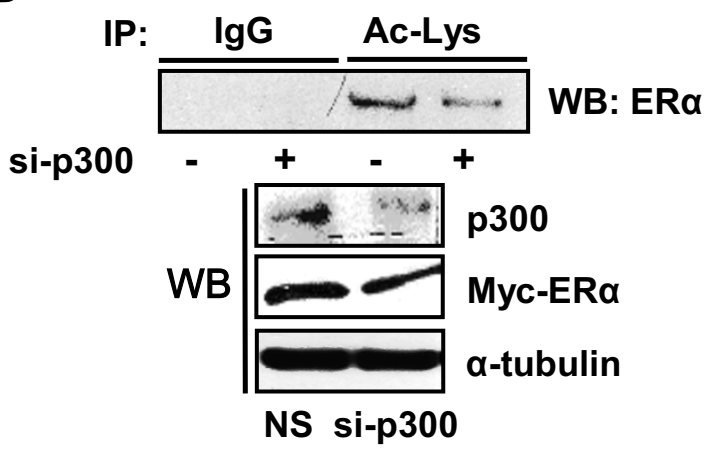

Figure 5 Knockdown of p300 decreases acetylation and stability of ERa protein. (a) T47D cells were transfected with si-p300 or nonspecific siRNA (NS) and treated with $1 \mu \mathrm{M}$ trichostatin A (TSA) for 3 hours. (b) HeLa cells were transiently transfected with $2 \mu \mathrm{g}$ Myc-ERa together with si-p300 or NS and treated with $1 \mu \mathrm{M}$ TSA for 3 hours. Then $500 \mu \mathrm{g}$ whole-cell lysate was immunoprecipitated (IP) using antiacetylated-lysine (Ac-Lys) or normal IgG antibodies, and probed using anti-ERa antibody. The expression of p300 and ERa was analyzed by western blot (WB) using anti-p300 or anti-Myc as input.

dent cell proliferation, further supporting the notion that modifying $E R \alpha$ acetylation strongly influences epithelial cell growth in breast tissue [41]. Further molecular details of the acetylation of $E R \alpha$ and the resulting estrogen signaling could contribute to a novel therapeutic strategy against breast cancer.

\section{Conclusions}

Several previous studies have demonstrated the role of TSA in regulation of $E R \alpha$, but the precise mechanism of how TSA affects ER $\alpha$ activity remains unclear. We report that TSA enhanced acetylation as well as the stability of the ER $\alpha$ protein by modulating the stability of $\mathrm{p} 300$. Our results may provide the molecular basis concerning pharmacological functions of histone deacetylase inhibitors against human breast cancer.

\section{Abbreviations}

ER: estrogen receptor; HDAC: histone deacetylase; PCR: polymerase chain reaction; RT: reverse transcriptase; TSA: trichostatin A.
Competing interests

The authors declare that they have no competing interests.

\section{Authors' contributions}

M-OL conceived of the study and its design, and interpreted the data. S-HK contributed to the study's conception and design, data collection and interpretation, and manuscript writing. $\mathrm{H}-\mathrm{JK}$ and $\mathrm{HN}$ partly contributed to the study's design and data collection. Both authors read and approved the final manuscript.

\section{Acknowledgements}

The present study was supported by grants from the NRF (2009-0080757) and from the SRC/ERC (R11-2007-107-01001-0).

\section{Author Details}

${ }^{1}$ College of Pharmacy, Seoul National University, San 56-1, Sillim-dong, Kwanak-gu, Seoul 151-742, Republic of Korea, ${ }^{2 B i o-M A X ~ I n s t i t u t e, ~ S e o u l ~}$ National University, San 56-1, Sillim-dong, Kwanak-gu, Seoul 151-742, Republic of Korea and ${ }^{3}$ Research Institute of Pharmaceutical Sciences, Seoul National University, San 56-1, Sillim-dong, Kwanak-gu, Seoul 151-742, Republic of Korea

Received: 1 September 2009 Revised: 30 January 2010

Accepted: 13 April 2010 Published: 13 April 2010

\section{References}

1. Enmark E, Gustafsson JA: Oestrogen receptors - an overview. J Intern Med 1999, 246:133-138.

2. Matthews J, Gustafsson JA: Estrogen signaling: a subtle balance between ERa and ERß. Mol Interv 2003, 3:281-292.

3. Shao W, Brown M: Advances in estrogen receptor biology: prospects for improvements in targeted breast cancer therapy. Breast Cancer Res 2004, 6:39-52.

4. Sunderland MC, MCGuire WL: Hormones and breast cancer. Trends Endocrinol Metab 1991, 2:72-76.

5. Early Breast Cancer Trialists' Collaborative Group: Tamoxifen for early breast cancer: an overview of the randomised trials. Lancet 1998, 351:1451-1467.

6. Lapidus RG, Nass SJ, Davidson NE: The loss of estrogen and progesterone receptor gene expression in human breast cancer. $J$ Mammary Gland Biol Neoplasia 1998, 3:85-94.

7. Fisher B, Costantiso JP, Wickerham DL, Cecchini RS, Cronin WM, Robidoux A, Bevers TB, Kavanah MT, Atkins JN, Margolese RG, Runowicz CD, James $J M$, Ford $L G$, Wolmark N: Tamoxifen for the prevention of breast cancer: current status of the National Surgical Adjuvant Breast and Bowel Project P-1 study. J Natl Cancer Inst 2005, 97:1652-1662.

8. Le Goff P, Montano MM, Schodin DJ, Katzenellenbogen BS: Phosphorylation of the human estrogen receptor. Identification of hormone-regulated sites and examination of their influence on transcriptional activity. J Biol Chem 1994, 269:4458-4466.

9. Likhite VS, Stossi F, Kim K, Katzenellenbogen BS, Katzenellenbogen JA: Kinase-specific phosphorylation of the estrogen receptor changes receptor interactions with ligand, deoxyribonucleic acid, and coregulators associated with alterations in estrogen and tamoxifen activity. Mol Endocrinol 2006, 20:3120-3132.

10. Wang C, Fu M, Angeletti RH, Siconolfi-Baez L, Reutens AT, Albanese C, Lisanti MP, Katzenellenbogen BS, Kato S, Hopp T, Fuqua SA, Lopez GN, Kushner PJ, Pestell RG: Direct acetylation of the estrogen receptor alpha hinge region by $\mathrm{p} 300$ regulates transactivation and hormone sensitivity. J Biol Chem 2001, 276:18375-18383.

11. Kim MY, Woo EM, Chong YT, Homenko DR, Kraus WL: Acetylation of estrogen receptor alpha by p300 at lysines 266 and 268 enhances the deoxyribonucleic acid binding and transactivation activities of the receptor. Mol Endocrinol 2006, 20:1479-1493.

12. Sentis S, Le Romancer M, Bianchin C, Rostan MC, Corbo L: Sumoylation of the estrogen receptor alpha hinge region regulates its transcriptional activity. Mol Endocrinol 2005, 19:2671-2684.

13. Berry NB, Fan M, Nephew KP: Estrogen receptor-alpha hinge-region lysines 302 and 303 regulate receptor degradation by the proteasome. Mol Endocrinol 2008, 22:1535-1551.

14. Glozak MA, Sengupta N, Zhang X, Seto E: Acetylation and deacetylation of non-histone proteins. Gene 2005, 363:15-23. 
15. Minucci S, Pelicci PG: Histone deacetylase inhibitors and the promise of epigenetic (and more) treatments for cancer. Nat Rev Cancer 2006, 6:38-51

16. Alao JP, Lam EW, Ali S, Buluwela L, Bordogna W, Lockey P, Varshochi R, Stavropoulou AV, Coombes RC, Vigushin DM: Histone deacetylase inhibitor trichostatin A represses estrogen receptor alpha-dependent transcription and promotes proteasomal degradation of cyclin D1 in human breast carcinoma cell lines. Clin Cancer Res 2004, 10:8094-8104.

17. Reid $G$, Metuvuer $R$, Lin CY, Denger S, Ibberson D, Ivacevic T, Brand $H$, Benes V, Liu ET, Grannon F: Multiple mechanisms induce transcriptional silencing of a subset of genes, including oestrogen receptor alpha, in response to deacetylase inhibition by valproic acid and trichostatin $A$. Oncogene 2005, 24:4894-4907.

18. Kawai H, Li H, Avraham S, Jiang S, Avraham HK: Overexpression of histone deacetylase HDAC1 modulates breast cancer progression by negative regulation of estrogen receptor alpha. Int J Cancer 2003, 107:353-358.

19. Leong H, Sloan JR, Nash PD, Greene GL: Recruitment of histone deacetylase 4 to the $\mathrm{N}$-terminal region of estrogen receptor alpha. $\mathrm{Mol}$ Endocrinol 2005, 19:2930-2942.

20. Saji S, Kawakami M, Hayashi S, Yoshida N, Hirose M, Horiguchi S, Itoh A Funata N, Schreiber SL, Yoshida M, Toi M: Significance of HDAC6 regulation via estrogen signaling for cell motility and prognosis in estrogen receptor-positive breast cancer. Oncogene 2005, 24:4531-4539.

21. Zhang K, Faiola F, Martinez E: Six lysine residues on c-Myc are direct substrates for acetylation by p300. Biochem Biophys Res Commun 2005 336:274-280

22. Patel JH, Du Y, Ard PG, Phillips C, Carella B, Chen CJ, Rakowski C, Chatterjee C, Lieberman PM, Lane WS, Blobel GA, MCMahon SB: The c-MYC oncoprotein is a substrate of the acetyltransferases hGCN5/PCAF and TIP60. Mol Cell Biol 2004, 24:10826-10834.

23. Yoo YG, Kong G, Lee MO: Metastasis-associated protein 1 enhances stability of hypoxia-inducible factor-1alpha protein by recruiting histone deacetylase 1. EMBO J 2006, 25:1231-1241.

24. Lassot I, Estrabaud E, Emiliani S, Benkirane M, Benarous R, MargottinGoguet F: p300 modulates ATF4 stability and transcriptional activity independently of its acetyltransferase domain. J Biol Chem 2005, 280:41537-41545.

25. Seo HW, Kim EJ, Na H, Lee MO: Transcriptional activation of hypoxiainducible factor-1alpha by HDAC4 and HDAC5 involves differential recruitment of p300 and FIH-1. FEBS Lett 2009, 583:55-60.

26. Hodges YK, Tung L, Yan XD, Graham D, Horwitz KB, Horwitz LD: Estrogen receptors alpha and beta: prevalence of estrogen receptor beta mRNA in human vascular smooth muscle and transcriptional effects. Circulation 2000, 101:1792-1798.

27. Han LP, Lu J, Pan LN, Wang XL, Shao YG, Han SY, Huang BQ: Histone acetyltransferase $\mathrm{p} 300$ regulates the transcription of human erythroidspecific 5-aminolevulinate synthase gene. Biochem Biophys Res Commun 2006, 348:799-806

28. Tompson PR, Wang D, Wang L, Fulco M, Pediconi N, Zhang D, An W, Ge Q, Roeder RG, Wong J, Levrero M, Sartorelli V, Cotter RJ, Cole PA: Regulation of the p300 HAT domain via a novel activation loop. Nat Struct Mol Biol 2004, 11:308-315.

29. Stiehl DP, Fath DM, Liang D, Jiang Y, Sang N: Histone deacetylase inhibitors synergize $p 300$ autoacetylation that regulates its transactivation activity and complex formation. Cancer Res 2007, 67:2256-2264

30. Vigushin DM, Ali S, Pace PE, Mirsaidi N, Ito K, Adcock I, Coombes RC: Trichostatin A is a histone deacetylase inhibitor with potent antitumor activity against breast cancer in vivo. Clin Cancer Res 2001, 7:971-976.

31. Das C, Kundu TK: Transcriptional regulation by the acetylation of nonhistone proteins in humans - a new target for therapeutics. IUBMB Life 2005, 57:137-149.

32. Ito A, Kawaguchi Y, Lai CH, Kovacs JJ, Higahiomoto Y, Appella E, Yao TP: MDM2-HDAC1-mediated deacetylation of $\mathrm{p} 53$ is required for its degradation. EMBO J 2002, 21:6236-6245.

33. Simonsson M, Heldin CH, Ericsson J, Gronroos E: The balance between acetylation and deacetylation controls Smad7 stability. J Biol Chem 2005, 280:21797-21803.
34. Li X, Zhang S, Blander G, Tse JG, Krieger M, Guarente L: SIRT1 deacetylates and positively regulates the nuclear receptor LXR. Mol Cell 2007, 28:91-106.

35. Fu M, Wang C, Reutens AT, Wang J, Angeletti RH, Siconolfi-Baez L, Ogryzko V, Avantaggiati ML, Pestell RG: p300 and p300/cAMP-response elementbinding protein-associated factor acetylate the androgen receptor at sites governing hormone-dependent transactivation. J Bio/ Chem 2000, 275:20853-20860

36. Goodman RH, Smolik S: CBP/p300 in cell growth, transformation, and development. Genes Dev 2000, 14:1553-1577.

37. Kawai H, Nie L, Wiederschain D, Yuan ZM: Dual role of p300 in the regulation of p53 stability. J Biol Chem 2001, 276:45928-45932.

38. Blanco-García N, Asensio-Juan E, de la Cruz X, Martínez-Balbás MA: Autoacetylation regulates P/CAF nuclear localization. J Bio/ Chem 2009, 284:1343-1352.

39. Yang XJ, Seto E: HATs and HDACs: from structure, function and regulation to novel strategies for therapy and prevention. Oncogene 2007, 26:5310-5318.

40. Sauve AA, Celic I, Avalos J, Deng H, Boeke JD, Schramm VL: Chemistry of gene silencing: the mechanism of $\mathrm{NAD}^{+}$-dependent deacetylation reactions. Biochemistry 2001, 40:15456-15463.

41. Lu R, Serrero G: Resveratrol, a natural product derived from grape, exhibits antiestrogenic activity and inhibits the growth of human breast cancer cells. J Cell Physiol 1999, 179:297-304.

\section{doi: $10.1186 /$ bcr2562}

Cite this article as: Kim et al., Trichostatin A enhances acetylation as well as protein stability of ER? through induction of p300 protein Breast Cancer Research 2010, 12:R22

\section{Submit your next manuscript to BioMed Central and take full advantage of:}

- Convenient online submission

- Thorough peer review

- No space constraints or color figure charges

- Immediate publication on acceptance

- Inclusion in PubMed, CAS, Scopus and Google Scholar

- Research which is freely available for redistribution
C) BioMed Central 